(under favourable conditions) of $10{ }^{\circ} \mathrm{C}$. The EEC directive goes into great detail about the monitoring of beaches where bathing is to be authorised or tolerated. (How does one deal with a bather who persists in bathing in a place which is not tolerated? The directive is silent on this point.) Monitoring must be carried out for each beach once a week, or once every two weeks, or once a month, depending on "the mean density of bathers per kilometre of beach" and bathing is defined as "prolonged immersion of the whole body". Bathing water is "deemed to conform to the mandatory values of the relevant parameters if $95 \%$ of the samples... . comply with the limits specified in column I of annexes 1 and 2". Now turn to the list of parameters in the annex. They include: total coliform, faecal coliform, faecal streptococci, Salmonella, viruses, $p \mathrm{H}$, mineral oils, surface active substances reacting with methylene blue, phenol indices, pesticides, and the following: As, $\mathrm{Cd}, \mathrm{Cr}, \mathrm{Pb}, \mathrm{Hg}, \mathrm{CN}$, $\mathrm{NO}_{3}$, phosphates and dissolved oxygen. Consider the task of carrying out these acts of monitoring, even for the major watering places round the coasts of Britain. The Department of the Environment hazarded a guess that the cost of complying with the directive might be of the order of $£ 100$ million a year. If there were a demonstrable health hazard this enterprise might be justified, but such data as we have (from a Medical Research Council report published in 1959) indicate that although many beaches in Britain are offensive to the eye and the nose, they are not a hazard to health; and the WHO still takes the view that "there are no internationally accepted criteria for the quality of coastal water for bathing with respect either to microbial contamination or chemical pollution".

There are no grounds for complacency about the state of the environment in Britain. We are certainly not in disagreement with the EEC's Declaration to protect the environment and we have, in the Control of Pollution Act, the best legislative arrangements in Europe for doing the job. The matter of principle, on which I hope Britain will stand firmly, is that each member state should be free to fulfil the objectives of the Community's environment policy in the light (as the Declaration states) "of health and ecological requirements"that is to say, taking into account the uses to which the environment is being put, and its capacity to dilute or disperse wastes. This is the basis of our pragmatic style of pollution control. This is the style we shall have to abandon if we cannot persuade the EEC to make its directives more flexible.

\section{Candle power at Browns Ferry}

In his third article on the state of the US nuclear industry, Colin Norman recalls the bizarre and dangerous accident at a nuclear power station earlier this year.

A FIRE, started by an electrician with a candle, disabled the Browns Ferry nuclear power station in Alabama on March 22, 1975, and sent shock waves through the nuclear industry. Officially described as the most serious accident to occur so far at an operating nuclear power plant in the United States, the fire knocked out several key safety systems, caused problems in shutting down one of the plant's two reactors, and rekindled the long-smouldering debate about nuclear safety.

A bizarre and dangerous accident which destroyed some 2,000 electric cables and caused millions of dollars worth of damage, the fire has put the Browns Ferry power station out of action for an indefinite period. It has also raised a number of serious questions about the vulnerability of nuclear power plants to such unforeseen incidents, and it may result in some costly modifications to other nuclear power stations in the United States.

The nuclear industry has, however, managed to salvage some good news from the incident. Although several key safety systems were disabled by the fire, enough reserve systems were left intact to shut the plant down safely and to avoid a major accident. That, industry spokesmen suggest, supports their contention that there are so many safety features built into a nuclear power station that if one device fails, others will be left to take over if necessary.

The Nuclear Regulatory Commission (NRC), the agency responsible for regulating the nuclear industry and ensuring that nuclear power plants are safe, shares that interpretation. In testimony before the Joint Committee on Atomic Energy last month, for example, the Chairman of the NRC, William A. Anders, said "we believe that this unfortunate and serious occurrence has shown that the reliance on the defence-in-depth concept is sound for the protection of public health and safety".

The NRC is now in the midst of analysing the Browns Ferry fire and its implications. It has already published a factual report on the accident, and in the next few weeks, the NRC will recommend changes in design and operating procedures at other nuclear power stations to prevent similar incidents from occurring elsewhere. Its report on the fire itself is a disquieting document which reveals an astonishing lack of fire precautions, considerable confusion during the fire fighting operations, and some quick thinking in the control room to avert a major nuclear disaster.

The fire began at about 1215 on March 22, when two reactors at Browns Ferry were each generating about $1,100 \mathrm{MW}$ of electricity. A third reactor, of similar size, was under construction. The fire was touched off by two electricians who were testing for air leaks around cables passing through the wall of a room enclosing the Unit 1 reactor.

The air in the reactor room is maintained at a lower pressure than the air outside, so that if radioactivity were released from the reactor, it would not immediately be dispersed into the atmosphere-fresh air would tend to leak into the reactor room rather than contaminated air out of it. The electricians were checking for leaks in a part of the wall separating the reactor room from a cable spreading room, immediately beneath the reactor's control panels. They were using the highly unofficial but time-honoured method of holding a lighted candle to the outside of the wall at the point where cables pass through it-if the candle flame is sucked horizontally, air is leaking from the cable spreading room into the reactor room.

An electrician's mate, who was doing the candle work, told NRC investigators that a fire started when the candle flame was sucked into a hole in the wall and ignited polyurethane foam surrounding some cables. $\mathrm{He}$ tried to beat out the smouldering foam with a flashlight, but succeeded only in burning the flashlight lens. He then tried to smother the fire with rags, but that didn't work. Somebody brought him a carbon dioxide fire extinguisher, but the $\mathrm{CO}_{2}$ blew straight through the hole without extinguishing the fire. Fanned by the air rushing through the hole, the fire began to get further back into the wall. He tried firing off two dry chemical fire extinguishers, but without success, and about 15 minutes after the fire started, the evacuation alarm sounded in the cable spreading room where he was working.

The cable spreading room was evacuated in preparation for triggering the permanent carbon dioxide fire extinguishing system. In the meantime, another electrician raised the alarm in a roundabout way (the correct fire alarm telephone number was not listed in some plant emergency manuals, so there was some confusion) 
and the reactor operators in the control room were notified of the fire. By that time, the burning had travelled through the hole in the wall into the reactor room, where several cable coatings had caught fire. Firefighting efforts there were hampered by the fact that the burning cables were about 40 feet above floor level. The local fire department was notified at 1309 and fire trucks arrived at 1330 from Athens, about 10 miles from the plant.

Among the alarming features of the firefighting effort noted by NRC investigators were the following:

- The carbon dioxide system initially failed to work because the power had been shut off and metal plates had been placed over the manual cranks to guard against accidents during construction work.

- Smoke in the reactor building was so dense that the room was evacuated at about 1300 , and "there appears to have been no central organised direction of the fire fighting efforts in this area until approximately 4.30 p.m." - Soon after he arrived at the plant, the Athens fire chief recommended spraying the fire with water, but the plant supervisor refused to allow use of water because of the danger of electrical shorts and injury to the fire fighters. He eventually sanctioned the use of water at about 1900 and the fire was extinguished within 15 minutes. It was formally declared to be out by 1945. By that time, the fire had damaged cables about 40 feet into the reactor room and a few feet inside the cable spreading room.

In contrast to the firefighting efforts, attempts to shut down the reactors were more successful, but no less dramatic. Because some key equipment had been disabled by the fire, the reactor operators were forced to use what the NRC coyly describes as "unconventional" methods to shut one of the reactors down and to avoid a potentially serious situation.

The reactors are controlled in a common control room immediately above the cable spreading room. The operator in charge of the Unit 1 reactor started noticing strange behaviour of various indicators on his control panel about five minutes after he had been notified of the fire. He was getting erroneous indications that pumps were running, some pumps cut in automatically, power output from the reactor began to drop, and several lights on the control board began glowing abnormally bright and then getting dim or going out. At 1251, the operator decided to shut the reactor down by inserting the control rods into the core, thereby cutting off the chain reaction (in operator's parlance, he manually 'scrammed' the reactor).

That successfully halted the nuclear reaction, but the problems then began. Because radioactivity decay of fission products in reactor fuel continues to heat the core long after the chain reaction is shut off, cooling water must be circulated through the core for many hours afterwards. Unless adequate cooling is provided, the reactor core could melt, burn its way through the concrete and steel floor of the pressure vessel and release large quantities of radioactivity into the environment. Because means of supplying cooling water to the reactor were knocked out by fire, the operator in charge of Unit 1 had to improvise.

Among the most important systems which were disabled was the emergency core cooling system (ECCS), a device which is supposed to flood the core with water if a pipe ruptures and the main cooling water is lost. The ECCS is used routinely during reactor shutdown operations.

According to the NRC report, and a description of the event provided to the Joint Committee on Atomic Energy last month by Donald $F$. Knuth, Director of the NRC's Office of Inspection and enforcement, the following sequence of events took place after the reactor was manually scrammed.

The water level surrounding the core dropped as a result of reduced boiling when the chain reaction was shut off. Consequently, pumps designed to inject water at high pressure into the reactor vessel increased their flow rate to keep the core covered with water. Soon after those pumps began running, however, a steam valve closed and disabled them. At that stage, the NRC report states, there was the following dangerous situation:

"The reactor coolant system had one remaining source of high pressure water, the control rod drive (CRD) system. Operator $\mathrm{M}$ (who was in control of Unit 1 operations) increased the CRD pump output to its maximum. Although the control room instrument has a maximum scale reading of 100 gallons per minute, Operator $M$ stated that he knew that the CRD pump was pumping greater than 100 g.p.m. but he does not know how much was being pumped. Operator $\mathbf{M}$ advised the investigators that he did not think that starting the spare CRD pump would have resulted in significantly greater injection flow, and he recalls that the spare CRD pump was not always operable during the shutdown".

In other words, there was only one reliable means of injecting high pressure water to the reactor, and that was being strained to its limit to maintain the coolant level around the core.

It soon became apparent that the SRD pump system couldn't maintain water level. It was therefore decided to open relief valves to reduce pressure in the reactor so that low pressure pumps could be used to supply cooling water. That tricky operation was carried out at about 1330, and the low pressure pumps provided sufficient water until about 1830 , when control over the relief valves was lost and they slammed shut. Pressure in the reactor began to build up, and the low pressure pumps were rendered inoperable.

The operator was then forced to switch back to the CRD system to supply high pressure water. That arrangement provided sufficient coolant until about 2150, when control over the pressure relief valves was restored and the reactor was again depressurised. About 13 hours after the fire began, temporary repairs were completed to allow the reactor to remain at low pressure, and at about 0430 , normal means of cooling the core were restored. By a series of extraordinary procedures, which have won praise from the NRC investigators, the reactor operators were therefore able to shut the plant down safely. But the incident nevertheless raises some very tricky questions.

Aside from the astonishing comedy of errors which led to the fire and caused it to burn for nearly 7 hours when it could have been extinguished with water in a few minutes, inadequacy in the design of the Browns Ferry plant was highlighted by the accident: a single fire, in a relatively small area of the plant disabled several key safety systems. Could a similar fire at another plant also have such potentially disastrous consequences?

Investigators from the NRC are now looking into the implications of the fire for other plants. According to Dr S. H. Hanauer, who is directing the investigation, important cables in plants built since Browns Ferry are more widely separated so that fewer key systems would be disabled by one fire. But "further improvements may be prudent in the light of the Browns Ferry lessons", Hanauer suggested, and he added that "some rerouting of cables may be necessary in some existing plants". Nevertheless, Hanauer stated that "based on our evaluation of the incident, we believe that even if a fire such as the one at Browns Ferry occurred in another existing plant, the most probable outcome would still be with no adverse effects on the public health and safety". The investigation, Hanauer said, "has not shown that present power plants are unsafe".

But the Browns Ferry fire had the makings of a very serious nuclear accident, and it has already provided plenty of ammunition for nuclear critics to shoot at the nuclear industry's otherwise good safety record. 